\title{
Transition of plant resins from the biosphere to the lithosphere
}

\section{Viktor M. Matsui \\ Uliana Z. Naumenko}

Institute of Geological Sciences of the NAS of Ukraine (Kyiv, Ukraine)

\begin{abstract}
Transition of plant resins from the biosphere to the lithosphere. - V. M. Matsui, U. Z. Naumenko. - In the article the authors consider in detail the process of transition of plant resins from the biosphere to the lithosphere, characterize the conditions and paleogeographic situation of such transition, the formation of deposits of resin minerals and placers of amber-succinitis in particular. The subject of research is the territory of the modern Dnipro brown coal basin within the Ukrainian Shield and its slopes, covering the border areas of the Pripyat Depression, Dnipro-Donetsk and Black Sea depressions, Volyn-Podilsk plate as a promising object of amber-succinitis genesis. A comprehensive geological and paleogeographic analysis of the natural conditions of this region in the Eocene-Oligocene was given. At that time, resin secretions of mainly conifers were accumulating in this area and transformed into fossil resins, which allowed the authors to distinguish three temporary stages of fossilization (fossilization and transformation) of the plant soft resin on the long path of transition from wildlife to inanimate. It was found that the fossilization of plant resins occurred in land-bog and marine stages under conditions of diagenesis. The first took place in the lower half of the Middle Eocene (the Lutetian); the second - in the post-Buchak time at the end of the Middle-Upper Eocene - Early Oligocene; the final stage is associated with the transformation of amber-succinite in the late diagenesis (Eocene-Oligocene) and catagenesis (Anthropogene) at low temperatures and pressure. For the first time, the primary source of amber-succinitis placers was identified, which was formed at the first, land-boggy stage of fossilization of plant resins. It is represented by biogenic-sedimentary deposits of resin secretions in peat bogs (proto-amber), underlying the "amber forests" and at some distance from them. The erosion of primary deposits took place in the post-Buchak time. The proto-amber taken from the primary sources was transported by river waters to the sea basin, where in a glauconite-containing medium, it acquired the properties of amber-succinitis. Establishment of the primary source of amber-succinite placers completely determines the scientific and practical significance of the research carried out, ultimately aimed to forecast deposits.
\end{abstract}

Key words: plant resins, stages of fossilization, amber-succinitis, proto-amber, placers.

\section{Introduction}

In Ukraine, there are large reserves of high-quality amber-succinitis. Deposits are developed only in the northwestern part of the territory - the Pripyat amber-bearing basin, where not rich in content (in average up to $200 \mathrm{~g} / \mathrm{cm}^{3}$ ), near-surface (from 1-2 to $20 \mathrm{~m}$ ), coastal-sea and lagoon-delta placers are found. Searches for large industrial AS placers of a different genesis have not been carried out in Ukraine, although there are objective prerequisites for the discovery of new types of industrial amber-succinitis placers confined to remote parts of the shelf of the marine paleobasin. Justification of the forecast for the identification of these placers in Ukraine is based on the study of the genesis and history of the transformation of plant resins, starting from the moment of the afflux of the soft resin to the formation of primary biogenic-sedimentary deposits of resin secretions before the formation of amber-succinitis in a marine glauconite-containing environment.

The purpose of the article is to present the results of the study on the specifics of the accumulation of resin secretions and the formation of a variety of resins, which depends on the conditions of their deposits and processes that took place in the area. The authors have established the primary source of amber-succinitis placers in Ukraine. The practical value of the obtained results is that their application should increase the efficiency and effectiveness of geological surveying, search and extraction of valuable gems.

Correspondence to: Uliana Naumenko; Institute of Geological Sciences of the NAS of Ukraine; Oles Honchar St. 55b, Kyiv, 01154 Ukraine; e-mail: uznaum@gmail.com; orcid: 0000-0001-9420-4044 


\section{Statement of the problem and its connection with important scientific and practical tasks}

P. A. Tutkovsky (1893) was the first to express the idea of a direct connection between the formation of amber and Eocene brown coal in the Dnipro brown coal basin. According to the scientist, almost the same trees that exuded resin eventually transformed into amber, also formed brown coal. This idea was substantiated at the beginning of this century in the bitumen-brown coal theory of the origin of amber-succinitis (Lebid' \& Matsui $2007 a-b, 2008$; Matsui 2016). The materials presented in the article open up real possibilities for identifying the primary sources of AS of the first intermediate reservoirs for the purpose of scientifically substantiated forecast of industrial deposits. Until now, the most important issue in the geology of AS placers - the genetic type and spatial position of the primary source - has not been finally resolved, which significantly limits the possibilities for forecasting placers in Ukraine, Belarus and the Baltic states. The factual data presented in the article contradict the ideas about hypothetical conifers of Scandinavia, due to the erosion of which AS placers were formed in the territory of the Baltic-Dnipro amber province. The authors also have serious objections to the idea of transferring amber to Ukraine from the North by glaciers, river waters, and coastal currents of the Early Paleogene seas, which is not supported by factual materials (Schultz 1960; Katinas 1971; Trofimov 1978).

Ukraine is part of the largest Baltic-Dnipro amber province, and within its territory at the beginning of the Middle Eocene (Buchak time) the primary biogenic-sedimentary deposits of resin secretions were formed, which are the original source of Ukrainian amber-succinitis placers (Fig. 1).

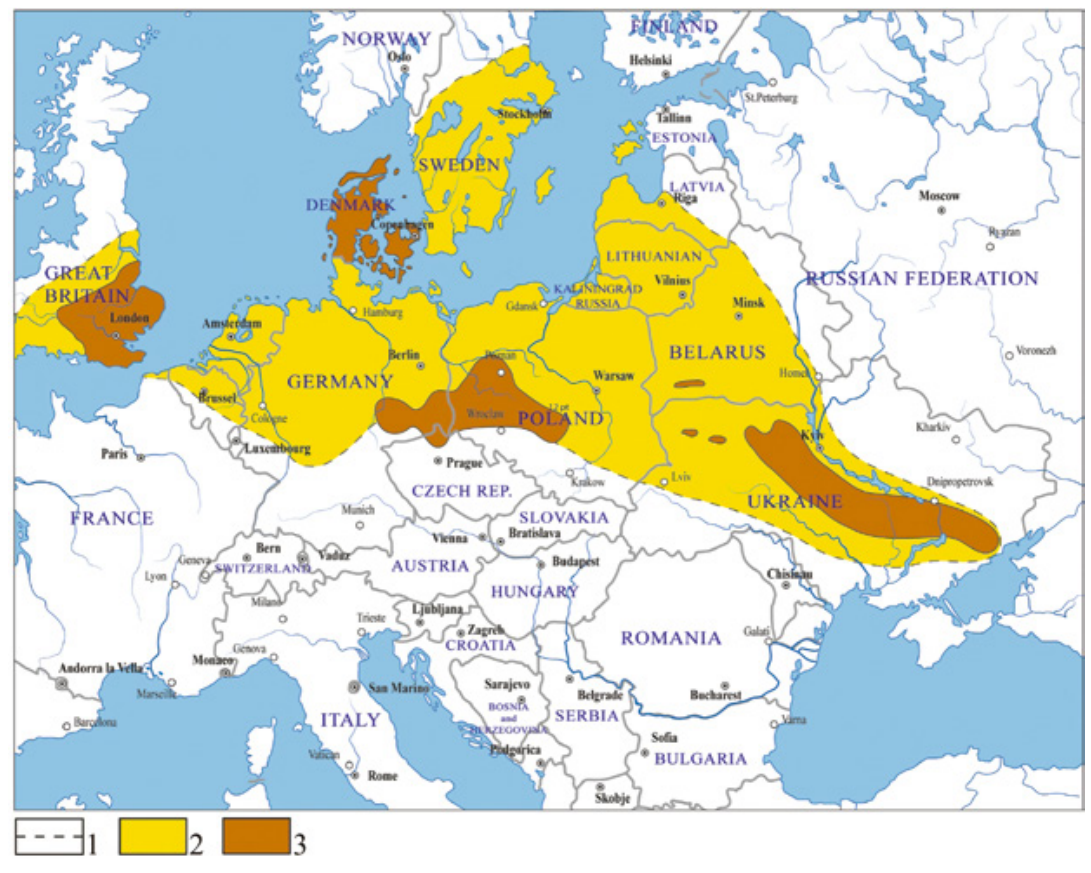

Fig. 1. Scheme of the territory of formation of primary biogenic-sedimentary deposits of tar secretions of proto-amber: 1 - presumed boundary of Middle Eocene paleotorphans - primary deposits of the protector, 2 - territory of partial or complete erosion of lignite layers in post-Buchak time, 3 - Middle Eocene coal basins. (after: Ladur 2013).

Рис. 1. Схема території формування первинних бiогенно-осадових покладів смоляних виділень протобурштину: 1 - передбачувана межа середньоеоценових палеоторфовищ - первинних покладів протобурштину, 2 - територія часткового або повного розмиву буровугільних нашарувань в постбучацький час, 3 середньоеоценові вугленосні басейни (за: Ладур 2013).

\section{Research results and their analysis}

Plant resins in a solution of essential oils (balms, soft resins) are formed by special rubbery tissues during the life of the plant and, especially, when it is damaged. Such tissues are contained mainly in bark, needles, wood and are maximally adapted to the texture of the tree. They protect plants from drying out, physical damage and decay. The transition of resin secretions into the state of fossil resins, during the transformation of plant residues under the influence of geological and geochemical factors, begins from the moment they flow to the day surface, when they no longer take part in the 
metabolism during the life of the plant. After that, they go through a very difficult and long path of fossilization through various physical and chemical transformations accompanied by movements. As a result, depending on the changing environmental conditions, various mineral types of fossil resins, natural organic formations of complex chemical composition, accumulated in the earth's interior. All the variety of fossil resins types is due to natural and facies conditions during sedimentation, which were changing in time and space.

A comprehensive analysis of the conditions of sedimentation of fossil resins in the territory of the Dnipro brown coal and other coal basins of the world allowed the authors to determine three main stages of fossilization of plant resins: 1) land-bog; 2) marine; and 3) hypergenic transformations of the AS in the process of late diagenesis and catagenesis.

The stages of fossilization and the natural setting during the transformation of resin into various mineral types of fossil resins, including their most valuable variety - amber-succinitis, were studied in detail in the 1970s by S. S. Savkevich (1970 a, b), V. I. Katinas (1971), and V. S. Trofimov (1974, 1978). They identified three stages of resin transformation, but in contrast to our scheme, these authors in the land-bog stage distinguished the processes of the outflow of the resin of amber-producing vegetation and its transformation on the surface and inside the soil as two separate stages. Additionally, their third stage corresponds to our second: erosion and accumulation of resin secretions (protoamber) in the sea during the formation of amber-succinitis placers in a marine glauconite-containing environment. S. S. Savkevich (1970) determined the main changes in fossil resins during hypergenic oxidation reasonably and in detail.

\section{Presentation of the main research materials}

\section{Land-bog stage of fossilization of plant resins}

The stage begins with the outflow of the resin of the reproducing vegetation during the life of the plant in the territory accessible for aeration; ends with the erosion and transfer of the proto-amber to the sea basin. At the stage of resin release, highly volatile components evaporated, resin substances thickened, polycondensed and oxidized on tree trunks, litter and in the soil of the "forests". The processes of weathering and oxidation of the soft resin took place at approximately $20{ }^{\circ} \mathrm{C}$ and free access of oxygen, simultaneously with its drying and subsequent thickening and hardening. At the stage of burial within the bog forests, swamps, and overgrown lakes, resin fossilization proceeded in the paleo-peat bogs in a redox environment. Under these conditions, the diagenesis of the resin took place in the process of biochemical coalification at high humidity and difficult access of oxygen. Thus, the stage of release of resin on the earth's surface with an increase in its density and hardening is interconnected and coupled in time and space with the stage of burial of soft resin in a continuously growing layer of decaying plant organic matter under the cover or at some distance from the "amber forest". Thus, these are the stages of a single land-bog stage of fossilization of plant resins with a duration of more than 1 million years. At this stage, primary biogenic-sedimentary deposits of proto-amber accumulated - the primary sources of amber-succinitis placers. Of course, the autochthonous deposits of the proto-amber were formed directly in situ of the growth of amber-producing vegetation; allochthonous biogenic-sedimentary deposits - at some distance from the main accumulation of biomass. The latter was composed of accumulations of fragments of small and large plants - trunks, branches, leaves, algae, etc. At present, similar forests of swamp cypress or taxodium growth are observed on the floods of the Mississippi river. Allochthonous fossil resins deposits in geological sections are found in strata of interbedded clays, sands, sandstones, brown coals with lenses of lignite and remains of charred wood.

In the territory of the Ukrainian Shield and its slopes, geographically corresponding to the modern Dnipro Basin at the beginning of the Middle Eocene (Buchak time), ideal conditions were formed for the lush growth of subtropical vegetation with elements of tropical and coal formation. This unique 
region is located on the right bank in the form of a wide strip stretching from north-west to southeast, covering the Zhytomyr, Kyiv, Cherkasy, Kirovohrad, Dnipropetrovsk, and Zaporizhzhya regions of Ukraine. The total area is 100 thousand $\mathrm{km}^{2}$. Here, about 120 deposits and coal shows with inclusions of fossil resins (retinites) have been identified at the site of widespread in the Buchak time paleo-peat bogs that were not eroded at the end of the Middle Eocene, which contained proto-amber. Paleofloristic data indicate that woody (90-95\%), angiosperms and gymnosperms subtropical, partly tropical evergreens served as the initial material for the formation of brown coal deposits. Of the gymnosperms subtropical forms, these are cypress, araucaria, taxodium, sequoia, legcarp, ginkgo, as well as well-known conifers Pinus Haploxylon and Diploxylon, Picea sp., Podocarpus. Of the angiosperms, these are magnolias, palms, olives, madder, myrtle, holly, heather, drimis, etc. (Syabryai 1958). The composition of plant associations of brown coals is close to the floristic composition of modern subtropical peatlands. According to F. S. Stanislavsky (1955), convincing remains of magnolia (prints of two leaves and a combined leaves) were found in the Buchak sandstones of the Karnikha stow near the village of Hulianka of Zhytomyr region not far from abandoned amber manifestation. In general, the vegetation of the Buchak period was close to the flora of modern southern Japan and southern parts of North America.

To conclude on the characteristics of the land-bog stage of fossilization of plant resins and the formation of primary biogenic-sedimentary deposits of the proto-amber we note that approximately similar geological processes took place in the same era in most of the Scandinavian Peninsula, in Germany, Poland, Russia (Kaliningrad region), and Belarus.

\section{Marine stage of resin secretions fossilization}

As a result of erosion of primary biogenic-sedimentary deposits, the amber enclosed in them was transported by river waters to various areas of accumulation, including the marine sedimentation basin. Within the latter, the burial of resin sediments took place in sandy-silty-clayey sediments with the participation of glauconite in the coastal and remote areas of the sea shelf.

The marine stage of fossil resin transformation is associated exclusively with post-Buchak marine transgressions: Kyiv, Obukhiv, and Mezhyhiria. The most intensive erosion of bitumen-containing brown coal layers and the influx of proto-amber into the coastal zone of sea basins occurred in the Late Eocene and Early Oligocene (Obukhiv and Mezhyhiria times) (Matsui 2011; 2016; Matsui \& 2019; Matsui et al. 2019).

The specificity of the processes of catagenesis of resin secretions washed out from primary sources and the specifics of the geochemical environment in the blue earth of the sea basin are described in detail by S. S. Savkevich $(1970,1983)$.

In the sea water body containing glauconite, only those bodies from the proto-amber substrate that were washed from the "mature" paleo-peat bogs preserved in the parts that are now represented by layers of brown coal could pass into amber-succinitis.

The geochemical situation of glauconite formation is characterized by a constant change of the redox potential and the alkaline reaction of the medium. In the alkaline environment, sludge waters containing oxygen and enriched with potassium interacted with the resin and contributed to a number of intermolecular transformations, which led to the formation of various oxy compounds and cleavage of succinic acid in the free state (Savkevich 1970: 163, 165). Chemical transformations of the resin were accompanied by the appearance of succinic acid and its esters, as well as organically bound sulfur and sulfides, and fragility reducing. At the same time, depending on the curves of the shoreline of the sea basin, the nature of the coastal currents in the coastal zone and remote parts of the shelf, the formation of amber-containing placers of the first intermediate reservoirs took place.

In Ukraine, for a short period of development and study of amber geology (since the end of the twentieth century), deposits of raw amber exclusively of coastal-marine and lagoon-delta genesis have been discovered and are currently being developed. The content of the useful component in them is significantly inferior to the Late Eocene Zambian - from 1-10 to a maximum of $200 \mathrm{~g} / \mathrm{m}^{3}$. 
The search for large deposits of AS of another genesis, such as the Zambian, associated with the remote part of the shelf, has never been conducted or predicted in Ukraine.

At the end of the Eocene-Early Oligocene, the volumes of direct erosion of the paleo-peat-forming seams of the Dnipro basin increased, due to which the mass of proto-amber accumulating in the coastal zone of the sea basin was constantly growing. As a result, the basal layers of the Mezhyhiria horizon today are the main treasury of Ukrainian amber. Mezhyhiria placers were enriched with valuable components both due to the input from the eroded primary sources, and the erosion and redeposition of amber from Obukhiv placers. The Middle Holocene placers of the Litorina Sea in the Baltic Sea were similarly formed due to the washing of the Late Eocene placers of 5500-2000 BC on the site of the modern Baltic water area.

\section{Hypergene transformation processes}

The final stage of the fossil resins and amber-succinatis transformations is currently takes place at low temperatures and pressure on the day surface, in water and underground at shallow depths. It was found that, in contrast to minerals of inorganic origin, fossilized resins do not have a constant elemental composition and do not have stable properties that change at depths and on the surface of Earth.

Amber in complete stratigraphic sections, not exposed by erosion, generally retains its properties and structure acquired earlier. In cases of its removal to the day surface, both by natural processes and human economic activity, it changes significantly under the influence of catagenesis. In placers, which were repeatedly washed in the Neogene, Pleistocene, and Holocene, and especially subjected to destructive human activity, the amber-succinatis under the influence of oxidation in hypergene conditions (air, light, fluctuations in humidity and temperature) changes the internal structure and color, an oxidative crust gradually appears, "saccharoid" nature and eventually grinding it into a fine powder.

According to S. S. Savkevich, various stages of hypergenic oxidation of fossil resins, especially amber (succinite), are also amenable to visual observation. First, these are color changes from dark yellow through orange to red and sometimes brown. After reaching the surface saturation limit with oxygen because of cleavage reactions, the resin surface becomes concentrated and microcracks appear, breaking the surface into small polygons. Along with contraction, the wedging effect of water can also contribute to the development of surface microcracks (Savkevich 1983: 104). In addition to color, the composition also changes - the oxygen content increases, the content of carbon, hydrogen, sulfur decreases; properties change. The Neogene-Anthropogenic alluvial manifestations, which were formed due to erosion and redeposition of the native Eocene-Oligocene, significantly differ, first of all, in the size of grain amber, the degree of roundness and, in general, in the preservation of specimens that are more resistant to weathering.

Archaeological amber from the economic complex of the Late Paleolithic settlements (18-14 thousand years) - villages of Mezhyrich (Ros river), Semenivka (Trubezh river basin), Dobranychivka (Supoy river), city of Rivne (Barmaky) and others allow assessing the degree of destruction of natural amber by human influence and time. Pieces of untreated and treated AS are distinguished by a uniform light yellow color with a slight pinkish tinge. The surface of these pieces is smooth, unevenly, but relatively deeply cut by randomly oriented polygonal cracks into irregularly shaped cellular joints. Small carbonate nodules, firmly soldered into pieces of amber, are distinguished. Most often, there are rounded volumetric concentrations of loose fragments of destroyed stone of various dimensions around a central (internal) slightly weathered transparent piece with a bright primary color of yellow or red. Moreover, the outer "shell" is composed of silty varieties of amber, closer to the center - sandy fractions, and coarser ones adjoin the weakly weathered center. Thus, we suggest that the destruction of the AS pieces occurred in the direction from the outer peripheral surface to the center. 
In a later burial during the excavations of the Hordiivskyi burial ground (end of the 2 nd millennium BC), there are more than 1500 amber items in the form of beads and pendants $0.4-5 \mathrm{~cm}$ in size. V. A. Shumova (2011) notes that artifacts in the air were intensively oxidized, which was expressed in the loss of color, transparency, coating the surface of amber items with patina and, finally, destruction of integrity. The destructive process of archaeological amber was halted only thanks to restoration and conservation measures using a vacuum method of fixing and by washing and rolling each sample with a solution of amber varnish, followed by fixing the surface with an organosilicon composition.

The English gemologist E. Frackey notes the disappearance of fluorescence in collection samples of Sicilian amber (simethite) of the 19th century. Without explaining the reasons for this phenomenon, which, in her opinion, should be the subject of a special study (Frakey 1990).

Workers of science and natural history museums are most familiar with the problem of AS destruction during storage indoors. Researchers at the Museum of the Land of the Polish Academy of Sciences and the Kaliningrad Amber Museum (Russia) not only record postdiagenetic transformations of amber, but also introduce recommendations and storage rules into everyday practical work that limit the negative effects of air, light and the internal structure of collection samples.

The problem associated with the transformation of amber-succinatis in catagenesis has not yet been resolved. It covers the issues of not only prolonging the "life" of the sun stone, but also qualitatively improving its unique properties, taking into account the wider use in medicine, agriculture, and various industries. In the XXI century, this problem can be solved by a comprehensive scientific analysis of nuclear substances and other mineral types of fossil resins at the molecular level.

\section{Conclusions}

The question on the geological nature, genetic type, and spatial position of the primary source of the European amber-succinitis placers has not yet had a final solution, and without establishing the location and geological nature of this source, as a result of the destruction of which the placers formed, their qualitatively substantiated prediction is impossible.

Considering the enormous scientific interest in the problem of the origin of fossil resins and especially its most valuable variety - amber-succinitis, the authors examine in detail the transition of plant resins from the biosphere to the lithosphere. It has been established that this transition and the formation of fossil resins and amber-succinitis deposits in the interior of the Earth is determined by natural features and facies conditions during sedimentation, alternating in time and space. A comprehensive analysis of the conditions of sedimentation of fossil resins in the territory of the Dnipro and other coal basins of the world allowed the authors to identify three main stages of fossilization (fossilization, likewise amber formation): land-bog, marine, hypergenic transformations in the process of late diagenesis and catagenesis, which are continuing to the present day.

At the first stage (the lower half of the Middle Eocene), in the territory of the low-lying land of the Dnipro Basin, in the substratum of producing trees, there was an accumulation and fossilization of resin secretions, mainly of coniferous trees. As a result, in conditions when soil formation was practically replaced by waterlogging and peat formation, the formation of primary biogenic-sedimentary deposits of proto-amber or the primary sources of amber-succinite placers took place. The stage covers lithological and geochemical processes at sedimentation and diagenetic stages under conditions of a humid type of lithogenesis. At this stage of transformation of plant resins, the whole variety of currently established mineral types of fossil resins was formed.

At the second stage of fossilization of plant resins in the post-Buchak time from the end of the Middle Eocene to the Early Oligocene, not ubiquitous erosion of the primary biogenic deposits of the proto-amber occurs. The erosion products, including proto-amber, were transported by river waters to various sedimentation basins, in which various mineral types of fossil resins were formed. In the sea basin, with the participation of glauconite, amber-succinitis was formed; and in the depressions of the Paleogene relief (freshwater and brackish-water basins), as well as in the territory of the not 
eroded and lowered part of the primary deposits of the coastal plains - fossil resins (retinite, crancite, rostornite, valchovite, sedarite and many others). The latter occur mainly in coal seams, lignites, coal shale, silt, sandstone interlayers. Common signs of these resins are a high degree of fragility, a very high solubility, the absence or insignificant percentage of succinic acid, etc.

Secondary fossil resins placers are subdivided into two orders: the first is amber-succinitis of the Baltic - Dnipro province and the second is sea placers that were subject to rock pressure and dislocation at the end of the stage of marine transformations (in the Ukrainian Carpathians, delatinite, Halician shraufite, in foreign countries - burmite, rumenite, simethite, etc.). The formation of these placers took place at the third stage of AS transformation at the stage of late diagenesis.

Amber-succinitis is a type of fossilized fossil resins of the Eocene-Oligocene, which passed the stage of fossilization in a marine glauconite-containing environment, followed by underground and surface variation in platform conditions. Characteristic features: viscosity (low brittleness), refractoriness, high degree of decorativeness, ease of processing (valuable raw material for jewelry and ornamental production), increased content of free succinic acid (up to 8-9\%), very noticeable solubility. It is distributed exclusively in placers due to erosion of layers of the Buchak paleo-peat bogs formed in the first half of the Middle Eocene.

\section{References}

Frakey, E. 1990. Amber. Mir, Moskow, 1-198. (In Russian)

Katinas, V. I. 1971. Amber and amber-bearing deposits in the South of the Baltic region. Minitis, Vilvius, 1-150. (In Russian)

Lebid', M. I., V. M. Matsui. 2007a. A probability the brown coal bitumen took part in the formation of amber placers origin. Ukrainian Geologist, 3: 62-68. (In Ukrainian)

Lebid', M. I., Matsui, V. M. 2007b. Spatial-time association of amber and brown coal in the Cenozoic of Europe. Ukrainian Geologist, 4: 16-18. (In Ukrainian)

Lebid', M. I., V. M. Matsui. 2008. Palaeogeographic Aspects of Amber Placers Forecast (on the basis of amberbrown coal hypotesis). Ukrainian Amber World: Proceedings of the First International Scientific and Practical Conference (Kyiv, October, 17, 2007). Kyiv, 38-45. (In Ukrainian)

Matsui, V. M. 2010. From plant resin of conifers to the amber-succinite. Proceedings of the National Museum of Natural History, 8: 135-142. (In Russian)

Matsui, V. M. 2011. Transformation of plant resins into fossil resins. Florology and Phytosozology. Vol. 2. Phyton, Kyiv, 290-294. (In Russian)

Matsui, V. M. 2016. Evolution of resin producing vegetation and the formation of fossil resins deposits. Naukova Dumka, Kyiv, 1-155.

Matsui, V. M., U. Z. Naumenko. 2019. Seashore and offshore amber-succinite placers in Ukraine. Geology and Mineral Resources of World Ocean, 4: 89-98. (In Russian)

Matsui, V. M., U. Z. Naumenko, O. L. Aleksandrov, G. O. Kuzmanenko. 2019. Problems of the Amber Polissia of Ukraine related to the development of amber-succinite deposits. Visnyk of the NAS of Ukraine, 11: 45-52. (In Ukrainian)

Savkevich, S. S. 1970. Amber. Leningrad, 1-191. (In Russian)

Savkevich, S. S. 1983. Processes of amber and some amber-like resins transformation depending on conditions of their formation and natural environment. Proceedings of the USSR Academy of Sciences, Series Geology, 12: 96-106. (In Russian)

Schultz, W. 1960. Die naturliche Verbreitung des Ostseebernsteins und das Bernsteinvorkommen von Stubbenfelde (Usedom). Zs. Angew. Geol., 12 (6): 610-664.

Shumova, V. O. 2011. Amber of the Hordiivskyi burial place. In: Klochko, V. I. (ed.). Hordiivskyi burial place. Vinnytsia, 270-275. (In Ukrainian)

Stanislavskyy, F. A. 1955. On the fossil remains of magnolia from the Paleogene deposits in the Ukrainian SSR. Geological Journal, 15, 1 (46): 65-69. (In Ukrainian)

Syabryai, V. T. 1958. Origin of the brown coal of the Dnipro Basin. Ukrainian SSR Academy of Sciences Publishing House, Kyiv, 1-78. (In Russian)

Trofimov, V. S. 1974. Amber. Nedra, Moscow, 1-184. (In Russian)

Trofimov, V. S. 1978. Main stages of amber transformation and principles of its classification. Proceedings of the USSR Academy of Sciences, Series Geology, 2: 128-138. (In Russian)

Tutkovsky, P. A. 1893. Kyiv amber. In: South-Western region. Popular natural history essays. Issue 1. Kyiv, $12-18$. (In Ukrainian) 